\title{
Do text discussions improve the academic skills of students of HE? Andorra University case
}

\section{Helena Prieto Sanz}

Interdisciplinary research group on Education, Universitat d'Andorra, Andorra.

\begin{abstract}
Reading is a core competency in learning processes of higher education as a tool for accessing discipline-specific knowledge. The aim of this case study is to analyse the impact of text group discussions on the academic skills of students at the Universitat d'Andorra (UdA). Qualitative techniques -nonparticipant observation, interviews and discussion groups- were applied to UdA students and faculty. Five student groups belonging to the Bachelor of Teaching and Learning (BTL), Bachelor of Computer Science (BCS) and Bachelor of Business Administration (BBA) were studied.

After processing the data with Atlas.ti, the first results were obtained. Evidences of a positive impact on the academic skills are identified. Firstly, both students and faculty indicated an improvement of the text comprehension mainly because of the peer interactions. Improvement of the critical and analitycal attitude, the own speech as well as the metacognitive learning are also highlighted as areas on which dialogic reading has positive impact.
\end{abstract}

Keywords: Text group discussions; dialogic reading; Higher Education. 


\section{Introduction}

Reading competence is an ability inherent in any learning process within the university academic context. It is a basic generic competence and an instrumental one (Tuning, 2003). University students use this skill in order to access to new and general knowledge of the discipline and at the same time to acquire other competences (Hjortshoj, 2001; Cassany, 2008; Carlino, 2013). Moreover, students need to overcome obstacles such as a lack of familiarity with technical vocabulary or becoming increasingly immersed in the academic subcultures of the communities to which they belong (Estienne \& Carlino, 2004; Gottschalk \& Hjortshoj, 2004).

A review of the scientific literature in line with the evidence-based teaching has been conducted in order to identify teaching strategies that promote reading proficiency at university level (Blouin et al., 2009; Schwartz \& Gurung, 2012). One of the teaching actions that has shown the best results in improving reading proficiency, according to the scientific literature, is text group discussions.

This strategy involves performing a first individual reading and then sharing the interpretations of the text with other readers. Text group discussion has been deeply analyzed. For example, the interactions established among the reading participants enhance their communication skills (Finke \& Edwards, 1997; Flood et al., 1994; Fredricks, 2012; Parrott \& Cherry, 2011). In the established dialogues, participants share their interpretations of the text and discuss them and, consequently, there is a more in-depth learning of the content worked from the text (Chocarro de Luis, 2013; Hamouda \& Tarlochan, 2015; Tynjälä, 1998). In addition, the dialogic environment favors that different contributions be linked to other knowledge in the same discipline and to other areas of knowledge that are not directly related to the text read (Macoun \& Miller, 2014).

Impact on academic skills also includes an improvement in analytical and critical capacity which is evident in the elaboration of participants' speeches. Tynjälä (1998) describes how from the perception of students themselves there is an increase in the development of thought. As the sessions progress, speeches become more complex, in-depth, and analytical, demonstrating that participants increase their analytical ability and relate different inputs from peers' contributions (Aguilar Ródenas, 2017; Carroll \& Sambolín Morales, 2016; Chirita, 2007; Flood et al., 1994; Tynjälä, 1998). In addition, reader discourse also improves because speech is argument-based and supported by literal references of the texts studied (Bixler et al., 2013).

Metacognitive learning is also promoted by text discussion. On the one hand, the way they learn is modified and the participants are aware of this phenomenon. The same protagonists express that they move from superficial to more global learning in the discipline by connecting new content to other theoretical frameworks of the discipline (Tynjälä, 1998). 
They are also aware that their interpretations and meanings are built on knowledge and past experiences (Jarvis, 2000; Tynjälä, 1998) and that their knowledge advance from an epistemological dualism to a relativism by discovering and understanding peers' interpretations (Bixler et al., 2013; Tynjälä, 1998).

In addition, learning belief is transformed from an individual to a collective process of meaning negotiation: it becomes an intersubjective construct of knowledge and meaning collaboratively creation (Aguilar Ródenas, 2017; Bixler et al., 2013; Chirita, 2007; Finke \& Edwards, 1997; Flood et al., 1994; Fredricks, 2012; Lake \& Evangelou, 2019; Tynjälä, 1998).

Within the framework of this study, in order to deepen students' reading habits, in April 2019 an anonymous, virtual survey of 26 faculty of Universitat d'Andorra (UdA) was applied. In general, lecturers consider students' reading habits to be very low (42.3\%), low $(26.9 \%)$ or medium $(26.9 \%)$ and a low $3.8 \%$ consider it high; in no case very high. Otherwise, the majority of the professors, $92.4 \%$, would like to foster a greater habit of academic reading among the students.

Being the group text discussion a strategy that has been widely studied and validated by the international scientific community, the present study seeks to implement this strategy at UdA and to analyze its impact.

\section{Method}

This research is a case study (Yin, 2009) with a communicative approach (Gómez, Latorre, Sánchez \& Flecha, 2006). The case study seeks to understand and shed light on a particular phenomenon in a certain context (Neiman \& Quarant, 2006). This case study aims to obtain an analysis of Universitat d'Andorra after implementing an specific teaching strategy.

\subsection{Context}

During the academic courses 2018-19 and 2019-20, five groups of UdA students have participated: two of Bachelor of Teaching and Learning (BTL) - 21 students enrolled, 21 years old on average-; one of Bachelor in Business Administration (BBA) -21 students enrolled, 24 years old on average- and two of Bachelor of Computer Science (BCS) -27 students enrolled, 27 years old on average-. The five groups have made a total of 18 readings: ten BTL, three BBA and six BCS.

Group text discussions have very diverse characteristics. Each teacher has chosen a typology of academic text: texts written by classic authors, newspaper articles, reports published by national or international institutions, and scientific articles. On the other hand, activity development has also varied in structure (small groups or large group discussions), 
resources used (reading patterns, previous activity, etc.) and task evaluation (task integrated into the evaluation or participation adds a point to the written work).

Notwithstanding the differences, all students have read individually the text, prepared a contribution, and shared their interpretations of the text using the printed or screen text to refer to specific quotes or parts of the text. In addition, all the text discussions have been developed within the framework of a course or seminar and in no case the activity has been optional.

\subsection{Data analysis}

Five interviews were conducted with UdA lecturers and nine discussion groups with UdA students. After processing the data with Atlas.ti, the analysis matrix was used (Table 1). This is defined by the subcategories extracted from the scientific literature and according to whether the information is considered a difficulty for the improvement of academic skills an excluder dimension - or an advantage - a transformative dimension-.

Table 1. Analysis matrix of the data obtained in the UdA study context.

\begin{tabular}{llcc}
\hline Category & Subcategory & $\begin{array}{c}\text { Excluder } \\
\text { Dimension }\end{array}$ & $\begin{array}{c}\text { Transformative } \\
\text { Dimension }\end{array}$ \\
\hline Academic & Impact on reading comprehension & 1.1 & 1.2 \\
skills & $\begin{array}{l}\text { Impact on analytical and critical } \\
\text { ability and speech }\end{array}$ & 2.1 & 2.2 \\
& Impact on metacognitive learning & 3.1 & 3.2 \\
\hline
\end{tabular}

Source: own elaboration.

The research is in line with the ethical guidelines adopted by various international organizations (European Science Foundation \& All European Academies, 2011). An Informed Consent was drawn up to ensure that the participants exercises their full freedom of choice.

\section{Results}

Below, Table 2 includes data collected pertaining to the transformative dimension, either from the information collection techniques applied to the faculty $(\mathrm{P})$ or the student $(\mathrm{A})$. 
Table 2. Analysis matrix of the data obtained in the UdA study context.

\section{Subcategory}

\section{Qualitative data}

1.1. Impact on BTL1920_P1: Yes, yes, I think they have improved reading comprehension. I reading have seen it in the examination of module 5. I see that reading is worked in class, comprehension then I always ask questions about the readings in some case and you see that the result is better, it is more optimal. They also linked the text to the challenge of Module 6.

BTL1819_P: Yes, today we were, for example, in the evaluation of practices in schools and (...) a lot of concepts came out of the Proximal Development Zone (PDZ) readings, adjusted help, previous knowledge ... There are many concepts in the subject of Educational Psychology that are very conceptual and the readings are also very conceptual but after the debate and the application they can better understand it.

BTL1819_A6: Yes because everything that is theoretical you can prepare it at home, that is you have the power point and I can read it but if I do not understand something then I will talk. "I did not understand this, did you understand? Okay, tell me! "

BBA1819_A3: Yes, of course, expand! (...) we never see it and when we start talking about it we see things that if you talk to people and there are many opinions and each one can expand a little bit. Yes, we expand the knowledge much more.

BBA1819_A4: to contextualize and the cases we talked about help me in the exam because I thought "oh, this is what we talked about last day in the Reading group", so I can apply there my knowledge.

BCS1819_A1: yes, because we were doing a debate that allowed us to see how to see it from another point of view of the challenge or the issue that was being faced, that is fine, also in terms of understanding concepts ... of course, being more scientific, maybe it was more difficult to understand or to handle and there is always another or other classmates that dominates more or understands it from another side and explains it to you from their side and you understand it.

BCS1920_A2: in the end when they are teaching you elaborate an idea and you think it is fine and when you argue with classmates you see that maybe your idea is not right, that maybe it is another thing, I think you learn much more. In the end, what you do is validate your idea.

BCS1819_A3: At least in my case... we expand the arc of knowledge, I think it is more cultural, culture of our career that is necessary some concepts that the teacher gives us. 
2.1 Impact on BCS1920_P: The comments were more mature because they had analyzed the analytical and graphs, results ... the comments were very "careful I see where you go!", "I find critical ability this very interesting or I do not see this much" ...

and speech

BTL1819_P: During the first reading they did not connect the text with the practices or other aspects, very summarized and very superficial. This has seen an improvement to the point where there were debates that brought them super interesting things, especially this. (...) his speech has improved greatly. And what has improved a lot is the use of subject-specific vocabulary. (...) And the readings help a lot in this, it is the way that they acquire the vocabulary of the subject.

BCS1920_A5: more specific! When people say an argument they say it more specific, for example, today with the blockchain many did not know what it was and have been able to explain it more concretely than what could be taken from the article.

BTL1819_P: Yes, they especially support their arguments better! It is not "I liked the practices very much, I liked what the teacher did", no! "I have seen the teacher activate the previous knowledge of students asking questions ...", that is, they can justify and argue, readings are key, it's key! Without reading and without this reflection, only with the lectures, is difficult, very difficult. Also the exam is much higher quality because of its ability to relate theoretical concepts and then the use of subject specific vocabulary, this is a significant improvement!

BTL1920_A5: what I see is that many times more than arguments are emotions and for me a debate must be in the arguments, in the facts ... in a debate you have to find a solution, not use the typical techniques to deny someone to to be right, or to appear to be right...

3.1 Impact on BTL1819_A6: To read a power point the truth is that I am bored! The important metacognitive thing is to explain it, that we all understand it, that I can explain it to you, that you learning can say "ah, I believe this!" And so, I don't know, it's like you understand it so much better! You get it! The things I remember most about studying and learning are the things I talked about...

BCS1920_A3: in the debate they would correct me at the moment and make me change the perspective of this, and I would not have the feeling that I have failed at that moment because here is my answer, here is the correction and it is not the same, it is a different concept, it is more a consensus than a correction.

\section{Discussion and conclusions}

Consistent with the perception of faculty, group text discussion has a positive impact on text comprehension, in line with Tynjälä (1998), Chocarro de Luis (2013), Hamouda and Tarlochan (2015), and Intriago's team (2016). Lecturers indicate that there has been an 
improvement in the resolution of exams and challenges in which the content of the reading is addressed.

On the other hand, students emphasize the importance of the interactions with group peers (Flood et al., 1994; Finke \& Edwards, 1997; Jarvis, 2000; Parrott \& Cherry, 2011; Fredricks, 2012). The improvement of the comprehension of the text lies in the possibility of sharing with the classmates their first interpretation of the text, the resolution of doubts and the formulation of questions to the classmates, as well as the ability to clarify their interpretation of the text from the contributions of colleagues.

The BCS1819 students also pointed out how the discussion of texts allowed them to "further expand the arch of knowledge, the culture of our career". Therefore, there is an improvement in one's own knowledge of the discipline and other areas of knowledge (Macoun \& Miller, 2014).

In terms of analytical and critical ability and speech improvement, both students and faculty affirm that there is a positive impact: speeches are more complex, in-depth and analytical (BTL1819, BCS1920), they make references in the text to arguing their speeches (BTL1819), they use the technical vocabulary more frequently (BTL1819) and elaborate more specific interventions (BCS1920). In general, the quality of the contributions is accused (Aguilar Ródenas, 2017; Chirita, 2007; Flood et al., 1994; Sambolin \& Carroll, 2015; Tynjälä, 1998).

In addition, an opinion-based turn of speech is also denoted by validity arguments (Finke $\&$ Edwards, 1997; Bixler et al., 2013; Aguilar Ródenas, 2017): students reflect on the need for support arguments, setting aside emotion and opinion (BTL1920) and professorate notice an improvement in argument elaboration (BTL1819).

Related to the metacognitive learning, students (BTL1819) particularly value interactions with peers as a source of knowledge, tending from an epistemological dualism to a relativism as knowledge is constructed based on different interpretations of colleagues (Tynjälä, 1998; BCSxler et al., 2013). Consequently, students (BTL1819) change their perceptions of an individual learning process to a collective one in which a continuous intersubjective construction of knowledge occurs (Flood et al., 1994; Finke \& Edwards, 1997; Tynjälä, 1998; Chirita, 2007; Bowers-Campbell, 2011; Fredricks, 2012; Bixler et al., 2013; Sambolin \& Carroll, 2015; Aguilar Ródenas, 2017). Therefore, they consider essential the involvement and participation of most peers in order to learn from all (BTL1819).

In the same line, it is stated that the difference between examining or discussing texts is that while the former is learned through corrections, the second is about consensus (BCS1920). 
At the same time, a change in the concept of reading is emphasized: from an individual reading to a reading understood as a social act (Finke \& Edwards, 1997; Jarvis, 2000).

\section{References}

Aguilar Ródenas, C. (2017). La tertulia pedagógica dialógica en el practicum de la formación inicial de maestras y maestros. Revista Iberoamericana de Educación, 73(2), 9-22. https://doi.org/10.35362/rie732198

Bixler, J., Smith, S., \& Henderson, S. (2013). Inviting Teacher Candidates into Book Talks: Supporting a Culture of Lifelong Reading. Reading Horizons, 52(3), 233-254.

Blouin, R. A., Riffee, W. H., Robinson, E. T., Beck, D. E., Green, C., Joyner, P. U., Pollack, G. M. (2009). Roles of Innovation in Education Delivery. American Journal of Pharmaceutical Education, 73(8).

Cassany, D. (2008). Prácticas letradas contemporáneas. México: Ríos de Tinta.

Carlino, P. (2013). Alfabetización académica 10 años después. Revista mexicana de investigación educativa, 18(57), 355-381.

Carroll, K. S., \& Sambolín Morales, A. N. (2016). Using university students' L1 as a resource: Translanguaging in a Puerto Rican ESL classroom. Bilingual Research Journal, 39(3-4), 248-262. https://doi.org/10.1080/15235882.2016.1240114

Chirita, S. (2007). Efl Literature Circles. Buletin USAMV-CN, 64(1-2), 693-698. https://doi.org/10.15835/buasvmcn-hort:2176

Estienne, V. \& Carlino, P. (2004). Leer en la universidad: enseñar y aprender una cultura nueva. Uni-Pluri/Versidad 4(3), 9-17.

European Science Foundation, \& All European Academies. (2011). The European code of conduct for research integrity. European Science Foundation.

Finke, J., \& Edwards, B. (1997). Teacher Education Students' Insights From Intergenerational Literature Circles. Journal of Teacher Education, 48(5), 367-378.

Flood, J., Lapp, D., Alvarez, D., Romero, A., Ranch-Buhr, W., Moore, J., Jones, M.A., Kabildis, K., \& Lungren, L. (1994). Teacher book clubs: a study of teachers' and student teachers' participation in contemporary multicultural fiction literature discussion groups. Reading Research Report No. 22, (National Reading Reserach Center (NRRC)), $1-32$.

Fredricks, L. (2012). The benefits and challenges of culturally responsive EFL critical literature circles. Journal of Adolescent and Adult Literacy, 55(6), 494-504. https://doi.org/10.1002/JAAL.00059

Gómez, J., Latorre, A., Sánchez, M., \& Flecha, R. (2006). Metodología comunicativa crítica. Barcelona: Hipatia.

Gottschalk, K. \& Hjortshoj, K. (2004). The elements of teaching writing, Boston: Bedford/St. Martin's.

Hamouda, A. M. S., \& Tarlochan, F. (2015). Engaging Engineering Students in Active Learning and Critical Thinking through Class Debates. Procedia - Social and Behavioral Sciences, 191, 990-995. https://doi.org/10.1016/j.sbspro.2015.04.379 
Hjortshoj, K. (2001). The transition to college writing. Boston: Bedford / St. Martin's. ISBN: 0312440820

Jarvis, C. (2000). Reading and knowing: How the study of literature affects adults? Beliefs about knowledge. International Journal of Lifelong Education, 19(6), 535-547. https://doi.org/10.1080/02601370050209069

Lake, G., \& Evangelou, M. (2019). Let's Talk! An interactive intervention to support children's language development. European Early Childhood Education Research Journal, 27(2), 221-240. https://doi.org/10.1080/1350293X.2019.1579549

Macoun, A., \& Miller, D. (2014). Surviving (thriving) in academia: feminist support networks and women ECRs. Journal of Gender Studies, 23(3), 287-301.

Neiman, G., \& Quaranta, G. (2006). Los estudios de caso en la investigación sociológica. Estrategias de investigación cualitativa, 1, 213-237.

Parrott, H. M., \& Cherry, E. (2011). Using structured reading groups to facilitate deep learning. Teaching Sociology, 394(4), 370. https://doi.org/10.1177/0092055X11418687

Sambolin, A. N., \& Carroll, K. (2015). Using literature circles in the ESL college classroom: A lesson from Puerto Rico. Colombian Applied Linguistics Journal, 17(2), 193. https://doi.org/10.14483/udistrital.jour.calj.2015.2.a02

Schwartz, B. M., \& Gurung, R. A. R. (Eds.) (2012). Evidence-based teaching for higher education. Washington, DC: American Psychological Association.

Tuning, P. (2003). Educational structures in Europe. Informe final fase I. Bilbao: Universidad de Deusto.

Tynjälä, P. (1998). Writing as a tool for constructive learning: Students' learning experiences during an experiment. Higher Education, 36(2), 209-230. https://doi.org/10.1023/A:1003260402036

Yin, K.R. (2009). Case Study Research. Design and Methods. Fourth Edition. Applied Social Research Methods Series. Volume 5. London: SAGE 